AL IBTIDA 3 (2): 212-226

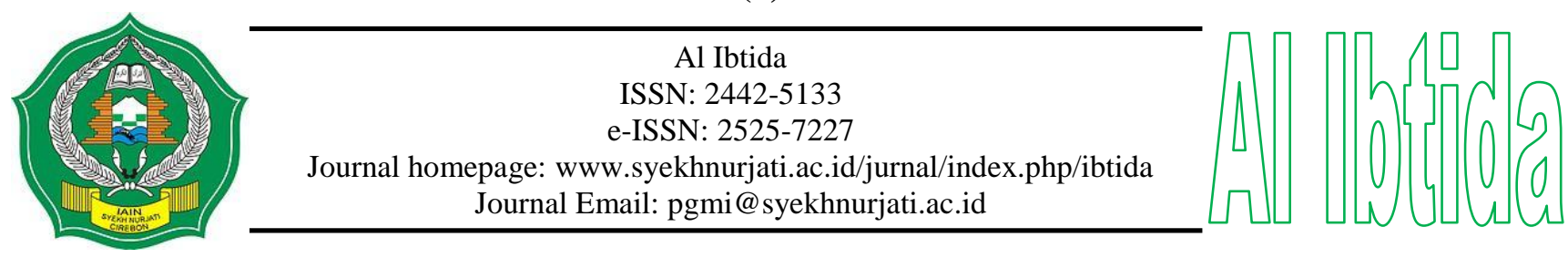

\title{
PORTOFOLIO SEBAGAI SALAH SATU MODEL PENILAIAN OTENTIK DI SD/MI
}

\author{
Itaristanti* \\ *FITK, IAIN Syekh Nurjati Cirebon \\ Email: itaristanti@yahoo.com
}

\begin{abstract}
Abstrak
Pembelajaran Kurikulum 13 (K13) berisi materi pembelajaran berbasis pada fakta atau fenomena yang dapat dijelaskan dengan logika atau penalaran tertentu; bukan sebatas kira-kira. Oleh karena itu, diperlukan sebuah alat penilaian yang tepat karena penilaian tidak akan lepas dari proses pembelajaran. Salah satu alat penilaian yang sesuai dengan perkembangan kurikulum tersebut adalah penilaian autentik. Secara konseptual, penilaian autentik lebih bermakna secara signifikan dibandingkan dengan tes pilihan ganda terstandar sekalipun. Penilaian otentik meliputi berbagai aspek pengetahuan siswa, pemahaman yang mendalam, kemampuan memecahkan masalah, kompetensi sosial, dan tingkah laku yang digunakan dalam kehidupan sehari-hari atau merupakan sebuah simulasi dari kehidupan nyata. Penilaian otentik merupakan kumpulan tugas-tugas bermakna dan menarik, kaya akan konteks, di mana siswa menerapkan pengetahuan dan keterampilan, serta menampilkan tugas-tugas tersebut dalam situasi yang baru. Tugas-tugas otentik membantu siswa berlatih menyelesaikan masalah-masalah yang akan mereka hadapi di masa mendatang. Salah satu contoh penilaian autentik adalah portofolio.
\end{abstract}

Kata kunci: penilaian autentik, portofolio.

\begin{abstract}
Curriculum 13 (K13) learning contains learning materials based on facts or phenomena that can be explained by the specific logic or reasoning; not approximate. Therefore, we need a proper assessment tools because assessing will not separated from the learning process. One assessment tool in accordance with the development of the curriculum is an authentic assessment. Conceptually, authentic assessment were significant compared with standardized multiple-choice tests though. Authentic assessment covers various aspects of students' knowledge, deep understanding, problem-solving skills,
\end{abstract}


social competence, and behavior that are used in everyday life or is a simulation of real life. Authentic assessment is a collection of tasks meaningful and interesting, rich in context, in which students apply their knowledge and skills, and displays the tasks in the new situation. Authentic tasks help students to practice solving the problems they will face in the future. One example of authentic assessment is the portfolio.

Keywords: authentic assessment, portfolio.

\section{PENDAHULUAN}

Penilaian merupakan hal yang tidak akan lepas dari proses pembelajaran. Perkembangan di seputar penilaian hasil pembelajaran siswa sejalan dengan perkembangan kurikulum yang dipergunakan. Hal itu disebabkan penilaian merupakan salah satu komponen yang terkait langsung dengan kurikulum. Kurikulum itu sendiri adalah seperangkat rencana dan pengaturan mengenai tujuan, isi, dan bahan pelajaran serta cara yang digunakan sebagai pedoman penyelenggaraan kegiatan pembelajaran untuk mencapai tujuan tertentu (PP No.19, Th. 2005: 3).

Pada kurikulum yang berlaku di Indonesia, baik KBK, KTSP maupun Kurikulum 2013, komponen penilaian memiliki peranan penting. Untuk mengukur tingkat ketercapaian kurikulum di jenjang sekolah, khususnya yang mencakup tujuan dan isi, penilaian terhadap capaian hasil pembelajaran mesti dilakukan. Menurut Nurgiyantoro (2008: 250-251), ada tiga fokus utama dalam pengembangan kurikulum berbasis kompetensi, yaitu penentuan kompetensi, pengembangan silabus, dan pengembangan penilaian. Komponen penilaian diyakini memberikan dampak nyata bagi keberhasilan pembelajaran kompetensi kepada siswa, maka penilaian kini ditempatkan pada posisi yang penting dalam rangkaian kegiatan pembelajaran. Bentuk dan cara penilaian dalam banyak hal memberikan pengaruh penting bagi proses pembelajaran, bagaimana guru harus membelajarkan dan bagaimana siswa harus belajar, dan karenanya menentukan capaian kompetensi.

Ada banyak definisi penilaian yang dikemukakan oleh pakar, yang, walau berbeda rumusan, pada umumnya menunjuk pada pengertian yang hampir sama. Istilah "penilaian" dalam bahasa Indonesia dapat bersinonim dengan "evaluasi" (evaluation) dan kini juga popular istilah "asesmen" (assessment). Menurut Linch (1996: 2) penilaian adalah usaha yang sistematis untuk mengumpulkan informasi untuk membuat pertimbangan dan keputusan. Brown (2004: 3) sengaja memilih istilah "tes" dan mengartikannya sebagai cara pengukuran keterampilan, pengetahuan, atau penampilan seseorang dalam konteks yang 
sengaja ditentukan. Penilaian juga diartikan sebagai proses pengumpulan dan pengolahan informasi untuk mengukur pencapaian hasil belajar peserta didik (PP No.19 Th 2005: 3).

Pelaksanaan KBK, KTSP, dan yang kemudian menjadi K13 di dunia pendidikan di Indonesia menuntut penggunaan model penilaian yang berbeda dengan penggunaan kurikulum-kurikulum sebelumnya. Dalam era KBK/KTSP, penekanan penilaian adalah pada kompetensi kinerja siswa sesuai dengan mata pelajaran. Siswa tidak hanya dituntut memahami aspek pengetahuan, melainkan juga apa yang dapat dilakukan dengan pengetahuannya itu. Begitu pula pada K13, materi pembelajaran berbasis pada fakta atau fenomena yang dapat dijelaskan dengan logika atau penalaran tertentu; bukan sebatas kirakira, khayalan, legenda, atau dongeng semata. Penjelasan guru, respons siswa, dan interaksi edukatif guru-siswa terbebas dari prasangka yang serta-merta, pemikiran subjektif, atau penalaran yang menyimpang dari alur berpikir logis (BPSDM, 2013: 2). Salah satu model penilaian yang sesuai dengan konsep tersebut adalah penilaian otentik. Sejalan dengan pelaksanaan KBK/KTSP, model penilaian otentik, yang di dalamnya terdapat model portofolio, kini menjadi sesuatu yang harus dilakukan.

\section{PEMBAHASAN}

\section{Hakikat Penilaian Otentik}

Penilaian autentik (authentic assessment) adalah pengukuran yang bermakna secara signifikan atas hasil belajar peserta didik untuk ranah sikap, keterampilan, dan pengetahuan. Istilah assessment merupakan sinonim dari penilaian, pengukuran, pengujian, atau evaluasi. Istilah autentik merupakan sinonim dari asli, nyata, valid, atau reliabel. Secara konseptual penilaian autentik lebih bermakna secara signifikan dibandingkan dengan tes pilihan ganda terstandar sekalipun. Ketika menerapkan penilaian autentik untuk mengetahui hasil dan prestasi belajar peserta didik, guru menerapkan kriteria yang berkaitan dengan konstruksi pengetahuan, aktivitas mengamati dan mencoba, dan nilai prestasi luar sekolah (BPSDM, 2013: 3).

Cara penilaian juga bermacam-macam, dapat menggunakan model nontes dan tes sekaligus, serta dapat dilakukan kapan saja bersamaan dengan kegiatan pembelajaran. Namun, semuanya harus tetap terencana secara baik. Misalnya, dengan memberikan tes (ulangan) harian, latihan-latihan di kelas, penugasan, wawancara, pengamatan, angket, catatan lapangan/harian, portofolio, dan lain-lain. Penilaian yang dilakukan lewat berbagai cara atau model, menyangkut berbagai ranah, serta meliputi proses dan produk inilah yang kemudian disebut sebagai penilaian otentik (Nurgiyantoro, 2012: 306). 
Penilaian otentik menekankan kemampuan pembelajar untuk mendemonstrasikan pengetahuan yang dimiliki secara nyata dan bermakna. Kegiatan penilaian tidak sekedar menanyakan atau menyadap pengetahuan yang telah diketahui pembelajar, melainkan kinerja secara nyata dari pengetahuan yang telah dikuasai. Sebagaimana dinyatakan Mueller (2008) penilaian otentik merupakan: a form of assessment in which students are asked to perform real-world tasks that demonstrate meaningful application of essential knowledge and skills. Jadi, penilaian otentik merupakan suatu bentuk tugas yang menghendaki pembelajar untuk menunjukkan kinerja di dunia nyata secara bermakna yang merupakan penerapan esensi pengetahuan dan keterampilan. Menurut Stiggins (melalui Mueller, 2008), penilaian otentik merupakan penilaian kinerja (perfomansi) yang meminta pembelajar untuk mendemonstrasikan keterampilan dan kompetensi tertentu yang merupakan penerapan pengetahuan yang dikuasainya.

Penilaian otentik meliputi berbagai aspek pengetahuan siswa, pemahaman yang mendalam, kemampuan memecahkan masalah, kompetensi sosial, dan tingkah laku yang digunakan dalam kehidupan sehari-hari atau merupakan sebuah simulasi dari kehidupan nyata. Penilaian otentik merupakan kumpulan tugas-tugas bermakna dan menarik, kaya akan konteks, di mana siswa menerapkan pengetahuan dan keterampilan, dan menampilkan tugas-tugas tersebut dalam situasi yang baru. Tugas-tugas otentik membantu siswa berlatih menyelesaikan masalah-masalah yang akan mereka hadapi di masa mendatang.

Jadi, penilaian model ini menekankan pada pengukuran kinerja, doing something, melakukan sesuatu yang merupakan penerapan dari ilmu pengetahuan yang telah dikuasai secara teoretis. Penilaian otentik lebih menuntut pembelajar mendemonstrasikan pengetahuan, keterampilan, dan strategi dengan mengkreasikan jawaban atau produk. Siswa tidak sekedar diminta merespons jawaban seperti dalam tes tradisional, melainkan dituntut untuk mampu mengkreasikan dan menghasilkan jawaban yang dilatarbelakangi oleh pengetahuan teoretis. Dalam penilaian kemampuan bersastra misalnya, pembelajar mampu menganalisis karakter tokoh dalam sebuah fiksi, mempertanggungjawabkan kinerjanya tersebut secara argumentatif, membuat resensi teks kesastraan, dan lain-lain.

Menurut Nurgiyantoro (2008: 253) tiap mata pelajaran tentu memiliki kriteria kinerja yang belum tentu sama dengan mata pelajaran yang lain. Kinerja hasil pembelajaran bahasa tentu tidak sama dengan hasil pembelajaran Matematika, Teknik 
Otomotif, Tata Busana, Seni Musik, dan lain-lain. Namun, pada prinsipnya semua mata pelajaran itu haruslah melaksanakan penilaian dan salah satunya dengan model penilaian otentik. Walaupun tiap mata pelajaran berbeda karakteristik, baik yang termasuk kategori ilmu-ilmu eksakta maupun sosial dan humaniora, kesemuanya tampaknya dapat menerapkan model penilaian otentik khususnya yang berupa portofolio.

\section{Perbedaan Penilaian Otentik dan Penilaian Tradisional}

Penilaian otentik sebenarnya telah lama dikenal di dunia pendidikan, tetapi baru terkenal di era KTSP. Sebenarnya, bentuk-bentuk penilaian otentik bukan merupakan barang asing bagi para pendidik di Indonesia. Hanya memang pada umumnya kita lebih akrab dengan penilaian model tradisional. Penilaian tradisional dalam kaitan ini dilihat sebagai penilaian yang lebih banyak menyadap pengetahuan yang telah dikuasai siswa sebagai hasil belajar yang pada umumnya ditagih lewat bentuk-bentuk tes objektif. Di pihak lain, penilaian otentik lebih menekankan pada pemberian tugas yang menuntut pembelajar menampilkan, mempraktikkan, atau mendemonstrasikan hasil pembelajarannya di dunia nyata secara bermakna yang mencerminkan penguasaan pengetahuan dan keterampilan dalam suatu mata pelajaran. Singkatnya, penilaian tradisional lebih menekankan tagihan penguasaan pengetahuan, sedang penilaian otentik kinerja atau tampilan yang mencerminkan penguasaan pengetahuan dan keterampilan.

Secara lebih konkret Mueller (2008) menunjukkan adanya persamaan dan perbedaan antara penilaian tradisional dan penilaian otentik. Penilaian tradisional antara lain memiliki karakteristik sebagai berikut.

a. Misi sekolah adalah mengembangkan warga negara yang produktif.

b. Untuk menjadi warga negara produktif, seseorang harus menguasai disiplin keilmuan dan keterampilan tertentu.

c. Maka, sekolah mesti mengajarkan siswa disiplin keilmuan dan keterampilan tersebut.

d. Untuk mengukur keberhasilan pembelajaran, guru harus mengetes siswa untuk mengetahui tingkat penguasaan keilmuan dan keterampilan itu.

e. Penilaian harus berdasarkan pada kurikulum.

Sementara itu, penilaian otentik memiliki karakteristik sebagai berikut.

a. Misi sekolah adalah mengembangkan warga negara yang produktif.

b. Untuk menjadi warga negara produktif, seseorang harus mampu menunjukkan penguasaan melakukan sesuatu secara bermakna dalam dunia nyata. 
c. Maka, sekolah mesti mengembangkan siswa untuk dapat mendemonstrasikan kemampuan/keterampilan melakukan sesuatu.

d. Untuk mengukur keberhasilan pembelajaran, guru harus meminta siswa melakukan aktivitas tertentu secara bermakna yang mencerminkan aktivitas di dunia nyata.

e. Penilaian mengarahkan pada kurikulum; guru pertama-tama menentukan tugas yang akan ditunjukkan sebagai keahlian mereka.

Selain hal-hal di atas, hal lain yang membedakan kedua jenis penilaian tersebut, jika dibuat secara pilah dikotomis adalah berupa perbedaan antara: (1) memilih jawaban dan menunjukkan suatu aktivitas; (2) menunjukkan penguasaan pengetahuan dan mendemostrasikan keahlian dengan melakukan sesuatu; (3) memanggil kembali atau rekognisi dan mengkonstruksi atau aplikasi; (4) soal dan jawaban disusun guru dan siswa menyusun sendiri jawaban; dan (5) bukti tidak langsung dan bukti langsung (faktual).

Perbedaan antara kedua model penilaian di atas sebenarnya tidak perlu dibesarbesarkan. Bagaimana pun juga, dalam kegiatan pembelajaran di sekolah, keduanya tetap saja sama-sama dibutuhkan. Kedua model itu memiliki keunggulannya masing-masing. Tagihan terhadap pengetahuan yang dimiliki pembelajar tidak dapat dikesampingkan begitu saja karena ia akan mendasari pembelajar untuk dapat berunjuk kerja secara benar, dan penguasaan terhadap pengetahuan itu lebih tepat diukur dengan tes tradisional. Namun, penilaian tidak benar jika hanya berurusan dengan hal-hal seperti itu. Kedua model penilaian tersebut disarankan sama-sama dipergunakan untuk mengukur kompetensi yang sesuai, tetapi dengan penekanan pada penilaian otentik. Jadi, penggunaan kedua model penilaian itu bersifat saling melengkapi.

\section{Manfaat Penggunaan Penilaian Otentik}

Karena penilaian otentik menekankan capaian pembelajar untuk menunjukkan kinerja, melakukan sesuatu, kesiapan pembelajaran untuk berunjuk kerja selepas mengikuti kegiatan pembelajaran tentu lebih signifikan. Selain itu, ada beberapa manfaat lain penggunaan penilaian otentik, sebagaimana dikemukakan Mueller (2008), yaitu sebagai berikut. Pertama, penggunaan penilaian otentik memungkinkan dilakukannya pengukuran secara langsung terhadap kinerja pembelajar sebagai indikator capaian kompetensi yang dibelajarkan. Penilaian yang hanya mengukur capaian pengetahuan yang telah dikuasai pembelajar hanya bersifat tidak langsung. Tetapi, penilaian otentik menuntut pembelajar untuk berunjuk kerja dalam situasi yang konkret dan sekaligus bermakna yang secara otomatis juga mencerminkan penguasaan dan keterampilan 
keilmuannnya. Unjuk kerja tersebut bersifat langsung, langsung terkait dengan konteks situasi dunia nyata dan tampilannya juga dapat diamati langsung. Hal itu lebih mencerminkan tingkat capaian pada bidang yang dipelajari. Misalnya, dalam belajar berbicara bahasa target, pembelajar tidak hanya berlatih mengucapkan lafal, memilih kata, dan menyusun kalimat, melainkan juga mempratikkannya dalam situasi konkret dan dengan topik aktual-realistik sehingga menjadi lebih bermakna.

Kedua, penilaian otentik memberi kesempatan pembelajar untuk mengkonstruksikan hasil belajarnya. Penilaian haruslah tidak sekadar meminta pembelajar mengulang apa yang telah dipelajari karena hal demikian hanyalah melatih mereka menghafal dan mengingat saja yang kurang bermakna. Dengan penilaian otentik pembelajar diminta untuk mengkonstruksikan apa yang telah diperoleh ketika mereka dihadapkan pada situasi konkret. Dengan cara ini pembelajar akan menyeleksi dan menyusun jawaban berdasarkan pengetahuan yang dimiliki dan analisis situasi yang dilakukan agar jawabannya relevan dan bermakna.

Ketiga, penilaian otentik memungkinkan terintegrasikannya kegiatan pengajaran, belajar, dan penilaian menjadi satu paket kegiatan yang terpadu. Dalam pembelajaran tradisional, juga model penilaian tradisional, antara kegiatan pengajaran dan penilaian merupakan sesuatu yang terpisah, atau sengaja dipisahkan. Namun, tidak demikian halnya dengan model penilaian otentik. Ketiga hal tersebut, yaitu aktivitas guru membelajarkan, siswa belajar, dan guru menilai capaian hasil belajar pembelajar, merupakan satu rangkaian yang memang sengaja didesain demikian. Ketika guru membelajarkan suatu topik dan pembelajar aktif mempelajari, penilaiannya bukan semata berupa tagihan terhadap penguasaan topik itu, melainkan pembelajar juga diminta untuk berunjuk kerja mempraktikkannya dalam sebuah situasi konkret yang sengaja diciptakan.

Keempat, penilaian otentik memberi kesempatan pembelajar untuk menampilkan hasil belajarnya, unjuk kerjanya, dengan cara yang dianggap paling baik. Singkatnya, model ini memungkinkan pembelajar memilih sendiri cara, bentuk, atau tampilan yang menurutnya paling efektif. Hal itu berbeda dengan penilaian tradisional, misalnya bentuk tes pilihan ganda, yang hanya memberi satu cara untuk menjawab dan tidak menawarkan kemungkinan lain yang dapat dipilih. Jawaban pembelajar dengan model ini memang seragam, dan itu memudahkan kita mengolahnya, tetapi itu menutup kreativitas pembelajar untuk mengkreasikan jawaban atau kinerjanya. Padahal, unsur 
kreativitas atau kemampuan berkreasi merupakan hal esensial yang harus diusahakan ketercapaiannya dalam tujuan pembelajaran.

\section{Pengembangan Penilaian Otentik}

Semua rangkaian dalam lingkup kegiatan belajar mengajar harus direncanakan dengan baik agar dapat memberikan hasil dan dampak yang maksimal. Hal inilah antara lain yang kemudian mendorong intensifnya penerapan teknologi pendidikan dalam dunia pendidikan. Perencanaan yang baik juga harus diterapkan dalam kegiatan penilaian yang menjadi bagian integral dari kegiatan pembelajaran.

Mueller (2008) mengemukakan sejumlah langkah yang perlu ditempuh dalam pengembangan penilaian otentik, yaitu yang meliputi (i) penentuan standar; (ii) penentuan tugas otentik; (iii) pembuatan kriteria; dan (iv) pembuatan rubrik.

\section{a. Penentuan Standar}

Standar dimaksudkan sebagai sebuah pernyataan tentang apa yang harus diketahui atau dapat dilakukan pembelajar. Di samping standar ada goal (tujuan umum) dan objektif (tujuan khusus), dan standar berada di antara keduanya. Standar dapat diobservasi (observable) dan diukur (measurable) ketercapaiannya. Istilah umum yang dipakai di dunia pendidikan di Indonesia untuk standar adalah kompetensi sebagaimana terlihat pada KBK dan KTSP. Di kurikulum tersebut dikenal adanya istilah standar kompetensi lulusan dan kompetensi dasar. Standar kompetensi lulusan adalah kualifikasi kemampuan lulusan yang mencakup sikap, pengetahuan, dan keterampilan (PP No. 19 Tahun 2005: 2), sedang kompetensi dasar adalah kompetensi atau standar minimal yang harus tercapai atau dikuasai oleh pembelajar.

Kompetensi, baik yang dirumuskan sebagai standar kompetensi maupun kompetensi dasar, menjadi acuan dan tujuan yang ingin dicapai dalam keseluruhan proses pembelajaran. Oleh karena itu, kompetensi apa yang akan dicapai itu haruslah yang pertama-tama ditetapkan. Untuk kurikulum sekolah (KTSP), standar kompetensi dan kompetensi dasar, yang dalam PP No. 19 Tahun 2005 tentang Standar Nasional Pendidikan disebut Standar Kompetensi Lulusan (SKL), telah secara jelas ditunjuk. Standar Kompetensi Lulusan inilah yang kemudian dijadikan pedoman penilaian dalam penentuan kelulusan peserta didik dari satuan pendidikan. Karena standar kompetensi dan kompetensi dasar lazimnya masih abstrak, kompetensi dasar kemudian dijabarkan menjadi sejumlah indikator yang lebih 
operasional sehingga jelas kemampuan, keterampilan, atau kinerja apa yang menjadi sasaran pengukuran.

Standar Kompetensi Lulusan tentu saja harus mencerminkan harapan masyarakat tentang apa yang mesti dicapai dan atau dikuasai oleh lulusan satuan pendidikan tertentu. Seiiring dengan perkembangan ilmu dan teknologi, dewasa ini perkembangan kehidupan begitu cepat. Dengan demikian, perubahan kini menjadi kata kunci untuk tetap bertahan. Maka, keterbukaan terhadap perubahan juga suatu hal yang harus diterima dan disikapi dengan benar. Konsekuensinya, salah satu kompetensi yang disiapkan untuk lulusan satuan pendidikan juga harus menerima dan mengikuti arus perubahan itu, dan itu artinya rumusan kompetensi harus realistik sesuai dengan tuntutan zaman.

b. Penentuan Tugas Otentik

Tugas otentik adalah tugas-tugas yang secara nyata dibebankan kepada pembelajar untuk mengukur pencapaian kompetensi yang dibelajarkan, baik ketika kegiatan pembelajaran masih berlangsung atau ketika sudah berakhir. Pengukuran hasil pencapaian kompetensi pembelajar yang secara realistik dilakukan di kelas dapat bersifat model tradisional atau otentik sekaligus tergantung kompetensi atau indikator yang akan diukur. Tugas otentik (authentic task) sering disinonimkan dengan penilaian otentik (authentic assessment) walau sebenarnya cakupan makna yang kedua lebih luas. Permasalahan yang segera muncul adalah tugas-tugas apa atau model-model pengukuran apa yang dapat dikategorikan sebagai tugas atau penilaian otentik.

Semua kegiatan pengukuran pendidikan harus mengacu pada standar (standar kompetensi, kompetensi dasar) yang telah ditetapkan. Demikian pula halnya dengan pemberian tugas-tugas otentik. Pemilihan tugas-tugas tersebut pertama-tama haruslah merujuk pada kompetensi mana yang akan diukur pencapaiannya. Kedua, dan inilah yang khas penilaian otentik, pemilihan tugas-tugas itu harus mencerminkan keadaan atau kebutuhan yang sesungguhnya di dunia nyata. Jadi, dalam sebuah penilaian otentik mesti terkandung dua hal sekaligus: sesuai dengan standar (kompetensi) dan relevan (bermakna) dengan kehidupan nyata. Dua hal tersebut haruslah menjadi acuan kita ketika membuat tugas-tugas otentik untuk mengukur pencapaian kompetensi pembelajaran kepada peserta didik. Dengan demikian, apa yang ditugaskan oleh guru kepada pembelajar dan yang dilakukan oleh pembelajar telah mencerminkan kompetensi yang memang dibutuhkan dalam 
kehidupan nyata. Hal itu berarti ada keterkaitan antara dunia pendidikan di satu sisi dengan tuntutan kebutuhan kehidupan di dunia nyata di sisi lain. Misalnya, dalam pembelajaran bahasa, bahasa target apa saja, pasti terdapat standar kompetensi lulusan yang berkaitan dengan kemampuan menulis. Menulis dalam kaitan ini bukan sekedar menulis demi tulisan itu sendiri, melainkan menulis untuk menghasilkan karya tulis yang memang dibutuhkan di dunia nyata. Misalnya, menulis surat lamaran pekerjaan, surat penawaran produk, menulis artikel untuk media masa, dan lain-lain. Untuk itu, pembuatan tugas-tugas otentik dalam rangka penilaian otentik capaian hasil belajar peserta didik mesti terkait dengan kemampuan menghasilkan karya tulis jenis-jenis tersebut.

c. Pembuatan Kriteria

Jika standar (kompetensi, kompetensi dasar) merupakan arah dan acuan kompetensi pembelajaran yang dibelajarkan oleh pendidik dan sekaligus akan dicapai dalam oleh subjek didik, proses pembelajaran haruslah secara sadar diarahkan ke capaian kompetensi yang telah ditetapkan sebelumnya.

Demikian pula halnya dengan penilaian yang dimaksudkan untuk mengukur kadar capaian kompetensi sebagai bukti hasil belajar. Untuk itu, diperlukan kriteria yang dapat menggambarkan capaian kompetensi yang dimaksud. Kriteria merupakan pernyataan yang menggambarkan tingkat capaian dan bukti-bukti nyata capaian belajar subjek belajar dengan kualitas tertentu yang diinginkan. Kriteria lazimnya juga telah dirumuskan sebelum pelaksanaan pembelajaran. Dalam kurikulum berbasis kompetensi kriteria lebih dikenal dengan sebutan indikator.

Dalam kegiatan pembelajaran, semua kompetensi yang dibelajarkan harus diukur kadar capaiannya oleh pembelajar. Jika dalam lingkup penilaian otentik harus melibatkan dua macam relevansi, yaitu sesuai dengan kompetensi dan bermakna dalam kehidupan nyata, kriteria atau indikator penilaian yang dikembangkan harus juga mengandung kedua tuntutan tersebut. Singkatnya, sebuah kriteria penilaian capaian hasil belajar harus cocok dengan kompetensi yang dibelajarkan dan sekaligus bermakna atau relevan dengan kehidupan nyata. Jumlah kriteria yang dibuat bersifat relatif, tetapi sebaiknya dibatasi, dan yang pasti kriteria harus mengungkap capaian hal-hal yang esensial dalam sebuah standar (kompetensi) karena hal itulah yang menjadi inti penguasaan terhadap kompetensi pembelajaran. Kita tidak mungkin menagih semua tugas yang dibelajarkan dan sekaligus dipelajari subjek didik. 
Selain itu, pembuatan kriteria harus mengacu pada ketentuan-ketentuan yang selama ini dinyatakan baik, baik dalam arti efektif untuk keperluan penilaian hasil belajar. Ketentuan-ketentuan itu antara lain: (a) harus dirumuskan secara jelas; (b) singkat padat; (c) dapat diukur, dan karenanya haruslah dipergunakan kata-kata kerja operasional; (d) menunjuk pada tingkah laku hasil belajar, apa yang mesti dilakukan dan bagaimana kualitas yang dituntut; dan (e) sebaiknya ditulis dalam bahasa yang dipahami oleh subjek didik. Perumusan kriteria yang jelas dan operasional akan mempermudah kita, para guru, untuk melakukan kegiatan penilaian.

d. Pembuatan Rubrik

Penilaian otentik menggunakan pendekatan penilaian acuan kriteria untuk menentukan nilai capaian subjek didik. Dengan demikian, nilai seorang pembelajar ditentukan seberapa tinggi kinerja ditampilkannya secara nyata yang menunjukkan tingkat capaian kompetensi yang dibelajarkan. Untuk menentukan tinggi rendahnya skor kinerja yang dimaksud, haruslah dipergunakan alat skala untuk memberikan skor-skor tiap kriteria yang telah ditentukan. Alat yang dimaksud disebut rubrik (rubric). Rubrik dapat dipahami sebagai sebuah skala penyekoran (scoring scale) yang dipergunakan untuk menilai kinerja subjek didik untuk tiap kriteria terhadap tugas-tugas tertentu (Mueller, 2008).

Dalam sebuah rubrik terdapat dua hal pokok yang harus dibuat, yaitu kriteria dan tingkat capaian kinerja (level of performance) tiap kriteria. Kriteria berisi hal-hal esensial standar (kompetensi) yang ingin diukur tingkat capaian kinerjanya yang secara esensial dan konkret mewakili standar yang diukur capaiannya. Dengan membatasi kriteria pada hal-hal esensial, dapat dihindari banyaknya kriteria yang dibuat yang menyebabkan penilaian menjadi kurang praktis. Selain itu, kriteria haruslah dirumuskan atau dinyatakan (jadi: berupa pernyataan dan bukan kalimat) singkat padat, komunikatif, dengan bahasa yang gramatikal, dan benar-benar mencerminkan hal-hal esensial (dari standar/kompetensi) yang diukur. Dalam sebuah rubrik, kriteria mungkin saja atau boleh juga dilabeli dengan kata-kata tertentu yang lebih mencerminkan isi, misalnya dengan kata-kata: unsur yang dinilai.

Tingkat capaian kinerja, di pihak lain, umumnya ditunjukkan dalam angkaangka, misalnya $1-5$. Besar kecilnya angka sekaligus menunjukkan tinggi rendahnya capaian. Tiap angka tersebut biasanya mempunyai deskripsi verbal yang diwakili, misalnya skor 1: tidak ada kinerja, sedang skor 5: kinerja sangat 
meyakinkan dan bermakna. Bunyi deskripsi verbal tersebut harus sesuai dengan kriteria yang akan diukur. Yang pasti terdapat banyak variasi dalam pembuatan rubrik, juga untuk kriteria dan angka tingkat capaian kinerja.

Penilaian tingkat capaian kinerja seorang pembelajar dilakukan dengan menandai angka-angka yang sesuai. Rubrik lazimnya ditampilkan dalam tabel, kriteria ditempatkan di sebelah dan tingkat capaian di sebelah kanan tiap kriteria yang diukur capaiannya itu. Misalnya, untuk mengukur kemampuan menulis puisi seorang siswa, dibuatkan rubrik sebagaimana tabel 1 berikut ini:

Tabel 1: Contoh Rubrik Penilaian Kemampuan Menulis Puisi

\begin{tabular}{|c|l|c|c|c|c|c|}
\hline \multirow{2}{*}{ No } & \multicolumn{2}{|c|}{ Aspek yang dinilai } & \multicolumn{5}{|c|}{ Tingkat Capaian Kinerja } \\
\cline { 3 - 7 } & & $\mathbf{1}$ & $\mathbf{2}$ & $\mathbf{3}$ & $\mathbf{4}$ & $\mathbf{5}$ \\
\hline 1 & Kesesuaian tema dengan isi & & & & & \\
\hline 2 & Pemilihan kata/ diksi & & & & & \\
\hline 3 & Penggunaan citraan & & & & & \\
\hline 4 & Permainan bunyi & & & & & \\
\hline 5 & Penyampaian amanat & & & & & \\
\hline
\end{tabular}

Rubrik dapat juga dibuat secara analitis (analytic rubrics) dan holistik (holistic rubrics). Rubrik analitis menunjuk pada rubrik yang memberikan penilaian tersendiri untuk tiap kriteria. Jadi, tiap kriteria mempunyai nilai tersendiri. Pada umumnya, rubrik bersifat analitis. Contoh di atas juga merupakan rubrik analitis. Rubrik holistik, di pihak lain, adalah yang tidak memberikan penilaian capaian kinerja untuk tiap kriteria. Penilaian capaian kinerja diberikan secara menyeluruh untuk seluruh kriteria sekaligus. Misalnya, penilaian diberikan dalam pernyataan verbal seperti: sedang, cukup, baik, amat baik; atau kurang memuaskan, memuaskan, amat memuaskan.

\section{Contoh Penilaian Otentik di SD/MI: Portofolio}

Salah satu penilaian otentik yang kini popular dipergunakan di dunia pendidikan di Indonesia adalah portofolio (portfolio). Bahkan, tampaknya di Indonesia penilaian model portofolio lebih dahulu dikenal para guru daripada penilaian otentik bersamaan dengan pelaksanaan KBK/KTSP. Tampaknya, tidak terlalu salah jika dikatakan bahwa salah satu trade mark penilaian era KBK/KTSP adalah dengan model portofolio. Kini, penilaian portofolio semakin ramai dibicarakan dan diakrabi para guru dan dosen yang mengajukan sertifikasi profesionalisme pendidik lewat pembuatan portofolio.

Penggunaan portofolio sebagai salah model penilaian hasil belajar bahasa dan sastra juga cocok karena dengan cara ini mahasiswa/siswa harus membuat karya tulis. Penilaian model portofolio juga menjamin memberikan data otentik tentang capaian 
kemampuan berbahasa. Penilaian portofolio merupakan salah bentuk penilaian berbasis kelas yang merupakan penilaian yang dilakukan dalam proses pembelajaran.

Di pihak lain, portofolio dapat dipahami sebagai sekumpulan karya yang disusun secara sistematis selama jangka waktu pembelajaran tertentu yang dipergunakan untuk memantau perkembangan pengetahuan, keterampilan, dan sikap peserta didik dalam suatu mata pelajaran (Supranata \& Hatta, 2004:21). Portofolio antara lain diperoleh lewat penugasan yang diberikan secara terencana dan terstruktur.

Jadi, selain untuk menilai hasil belajar peserta didik, portofolio juga dapat difungsikan sebagai sarana untuk memantau perkembangan kemajuan belajar. Pemahaman yang tidak berbeda dikemukakan oleh Mueller (2008) yang menyatakan bahwa portofolio adalah kumpulan karya peserta didik yang secara khusus diseleksi untuk menunjukkan keadaan secara khusus keadaan peserta didik.

Portofolio merupakan bukti (evidence) pengalaman yang dihasilkan sepanjang waktu pembelajaran yang dijadikan objek penilaian. Penilaian model portofolio tepat untuk melatih siswa atau mahasiswa menghasilkan karya tulis secara konkret, faktual, dan kontekstual. Karya yang diperoleh adalah hasil kerja langsung mahasiswa, maka portofolio merupakan bahan untuk penilaian otentik sekaligus penilaian kinerja (performance assessment). Barton \& Collins (1997, dalam Supranata \& Hatta, 2004: 2526) membedakan objek penilaian portofolio (evidence) ke dalam: (1) hasil karya peserta didik (artifacts): hasil kerja yang dilakukan di kelas; (2) reproduksi (reproduction): hasil kerja peserta didik yang dilakukan di luar kelas; (3) pengesahan (attestations): pernyataan dan hasil pengamatan guru/pihak lain terhadap peserta didik; dan (4) produksi (productions): hasil kerja peserta didik yang sengaja dipersiapkan untuk portofolio.

Penilaian portofolio haruslah sesuai dengan tujuan atau kompetensi yang akan diukur. Karena portofolio dapat bermacam-macam tergantung tujuan yang ingin dicapai, pembuatan portofolio haruslah secara jelas untuk menunjukkan kompetensi yang mana. Misalnya, apakah yang menyangkut kompetensi kognitif, psikomotor, atau afektif. Untuk tampilan ranah kognitif juga dapat dibedakan ke dalam berbagai macam portofolio. Misalnya, portofolio yang dimaksudkan untuk mengetahui perkembangan kemampuan menulis: menulis ilmiah, menulis berbagai bentuk surat, menulis iklan, menulis kreatif, dan lain-lain. Selain itu, penilaian portofolio juga berkaitan dengan berapa jumlah karya yang dibutuhkan, bagaimana cara memilih dan melibatkan peserta didik yang bersangkutan, bagaimana cara menilai (misalnya dengan mengembangkan 
rubrik), dan lain-lain. Pengembangan rubrik untuk tiap jenis portofolio belum tentu sama, tergantung komponen yang akan diukur.

Contoh penilaian otentik model portofolio pada kemampuan pembacaan puisi di kelas V SD/MI sebagaimana tabel 2 berikut ini:

Tabel 2. Contoh Rubrik Penilaian Kemampuan Membaca Puisi

\begin{tabular}{|c|l|c|c|c|c|c|}
\hline \multirow{2}{*}{ No } & \multicolumn{1}{|c|}{ Aspek yang dinilai } & \multicolumn{5}{|c|}{ Tingkat Capaian Kinerja } \\
\cline { 3 - 7 } & & $\mathbf{1}$ & $\mathbf{2}$ & $\mathbf{3}$ & $\mathbf{4}$ & $\mathbf{5}$ \\
\hline 1 & Volume suara & & & & & \\
\hline 2 & Ekspresi & & & & & \\
\hline 3 & Intonasi & & & & & \\
\hline 4 & Kelancaran & & & & & \\
\hline 5 & Kepercayaan diri & & & & & \\
\hline
\end{tabular}

Dengan model penilaian seperti ini, capaian kinerja siswa dalam pembacaan puisi dapat diketahui dari lima kriteria, yaitu volume suara, ekspresi, intonasi, kelancaran, dan kepercayaan diri. Skor tertinggi ditunjukkan dengan angka 5, sedangkan skor terendah ditunjukkan dengan angka 1.

\section{SIMPULAN}

Akibat tuntutan zaman yang begitu cepat berkembang, dunia pendidikan haruslah secara aktif melakukan berbagai inovasi baik yang menyangkut isi, kompetensi, proses, penilaian, maupun berbagai aspek terkait lain-lain yang ditunjuk dalam standar nasional pendidikan. Aspek penilaian merupakan salah satu kunci yang menentukan tujuan kompetensi pembelajaran. Oleh karena itu, masalah penilaian memang sudah selayaknya mendapat perhatian yang memadai. Namun demikian, berkembangnya teori yang baru haruslah disikapi secara kritis terutama yang berkaitan dengan keefektifan dalam pemanfaatannya secara nyata.

Kemunculan dan berkembangnya teori atau model-model penilaian yang baru tidak berarti meninggalkan sama sekali model-model sebelumnya yang belum tentu kurang baik. Tampaknya, yang lebih bijak adalah memanfaatkan keduanya sejauh relevan dan efektif dengan tujuan penilaian. Demikian pula halnya dengan pemanfaatan model penilaian tradisional dan model penilaian otentik. 


\section{DAFTAR PUSTAKA}

Badan Pengembangan Sumber Daya Manusia. (2013). Konversi Sertifikat Pendidik dan Perluasan Kewenangan Mengajar sesuai Kurikulum 2013. Jakarta: Kementerian Pendidikan dan Kebudayaan.

Brown, Douglas H. (2004). Language Assessment, Principle and Classroom Practices. San Francisco: Longman.

Lynch, Brian K. (1996). Language Program Evaluation. Cambridge: Cambridge University Press.

Mueller, John. (2014). Authentic Assessment Toolbox. North Central College Neperville, http://jonathan.mueller.faculty.noctrl.edu/toolbox/index.htm (Diunduh pada 7 April 2015).

Nurgiyantoro, Burhan. (2012). Penilaian Pembelajaran Bahasa. Yogyakarta: BPFE.

------. (2008). "Penilaian Otentik". Cakrawala Pendidikan, XXVII, No. 3, 250-261.

Peraturan Pemerintah Republik Indonesia Nomor 19 Tahun 2005 tentang Standar Pendidikan Nasional.

Sugiyono. (2005). Memahami Penelitian Kualitatif. Bandung: Alfabeta.

Supranata, Sumarna dan Muhammad Hatta. (2004). Penilaian Portofolio, Implementasi Kurikulum. Bandung: Rosda Karya. 